\title{
En ung mann med brystsmerter
}

\author{
Brystsmerter er en vanlig årsak til innleggelse i sykehus. Noen ganger \\ kan et fremtredende funn ved undersøkelsen peke i feil retning og føre \\ til at man overser viktige funn av stor klinisk betydning.
}

Engelsk oversettelse på www.tidsskriftet.no

Se kommentar side 1876

\author{
Marit Høysæter Hedger* \\ marit_hedger@hotmail.com \\ Sahrai Saeed* \\ Medisinsk avdeling \\ Ålesund sjukehus
}

* Nåværende adresser:

M.H. Hedger, Radiologisk avdeling

Ålesund sjukehus

S. Saeed, Hjerteavdelingen

Haukeland universitetssykehus

En mann i begynnelsen av 20-årene ble innlagt ved medisinsk avdeling på lokalsykehus grunnet brystsmerter av nesten to døgns varighet. Smertene startet sentralt i brystet og flyttet seg etter hvert over mot venstre side. De forverret seg ved dyp innpust og $i$ venstre sideleie. Pasienten hadde ingen andre symptomer. To uker forut for innleggelsen hadde han liknende brystsmerter som bedret seg spontant, og en måned før innleggelsen hadde han hatt forkjølelsessymptomer. Pasienten var ellers tidligere frisk og brukte ingen medisiner eller rusmidler. Det var ingen opphopning av hjertesykdom i familien.

Brystsmerter fører ofte til akutt innleggelse i sykehus. Hos noen er det et symptom på alvorlig patologisk forandring, mens hos andre kan det skyldes benigne, selvbegrensende tilstander. Årsakene kan deles inn i kardiale og ikke-kardiale. Ung alder taler oftest imot kardial årsak til smertene, slik som koronar hjertesykdom, mens pneumothorax og viral perikarditt er hyppige årsaker i aldersgruppen 20-40 år (1).

Pasientens allmenntilstand var god, men han var lett smertepåvirket. Ved undersøkelse var pasienten afebril med normale vitale parametre inkludert sidelik puls i overekstremitetene og begge lysker. Over lungene hørtes sidelike, svake respirasjonslyder og ingen fremmedlyder. Ved auskultasjon over hjertet hørtes en kraftig gnidningslyd over hele prekordiet. Lyden overdøvde nesten hjertetonene. I tillegg hørtes i venstre sideleie en «surklelyd» fra apex. Denne surklelyden var hørbar også uten stetoskop. Ictus ble palpert i midtklavikulærlinjen. Øvrig klinisk undersøkelse var normal. Elektrokardiogram (EKG) viste sinusrytme uten tegn til iskemi eller andre patologiske forhold.

Gnidningslyden gjorde at vi vurderte perikarditt som den mest aktuelle diagnosen, mens brystsmertene som forverret seg ved dyp inspirasjon kombinert med pasientens alder og allmenntilstand også gjorde pneumothorax til en differensialdiagnose. Gnidningslyden kunne også skyldes pneumomediastinum eller pleuritt. Lungeemboli kan gi respirasjonsavhengige smerter og både lungeemboli og dissekerende aortaaneurisme kan i sjeldne tilfeller gi fremmedlyd som minner om lyden som høres ved perikarditt $(2,3)$. Smerter i thorax ved dyp respirasjon kan også skyldes myalgi, men vi anså det som en mindre sannsynlig diagnose på grunn av fremmedlyden. Noe av det første vi ønsket å avklare var en eventuell affeksjon av hjertet, og da var EKG og telemetri naturlige valg kombinert med blodprøver. I tillegg ble røntgen thorax ansett som et naturlig ledd $i$ utredningen.

Vi rekvirerte blodprøver i form av infeksjonsprøver (C-reaktivt protein, senkningsreaksjon og leukocytter), elektrolytter, hemoglobin, Ddimer (fibrinnedbrytningsprodukt) og myokardenzymer (troponin I og CK-MB). Det ble tatt røntgen thorax under inspirasjon og ekspirasjon for å se etter pneumothorax. Det ble også tatt prøver til serologisk undersøkelse med tanke på myokarditt av viral genese (cytomegalovirus, enterovirus, Epstein-Barrvirus, adenovirus eller parvovirus $B$-19).

Pasienten ble observert med telemetri gjennom natten, uten tegn til rytmeforstyrrelser eller iskemi. Ekkokardiografi ble utført neste dag og viste ingen sikre tegn til perikarditt. Røntgen thorax ble beskrevet som normalt. Alle blodprøvene var innenfor referanseområdene. Serologi viste tegn på tidligere gjennomgått infeksjon med cytomegalovirus.

Han fikk diagnosen perikarditt av antatt viralt opphav og ble behandlet med inflammasjonsdempende medikamenter i form av naproksen. Dagen etter innleggelsen ble han utskrevet $i$ god allmenntilstand og tilnærmet smertefri.

På grunn av normale vitale parametre og ingen dyspné, ble mer alvorlige diagnoser som aortadisseksjon og lungeemboli vurdert som lite sannsynlige. Sidelik puls i begge armer og lysker talte også mot aortadisseksjon. D-dimer, som nær alltid stiger ved lungeemboli og oftest ved aortadisseksjon var også normal hos vår pasient. De normale røntgenbildene av lungene gjorde pneumothorax eller pneumomediastinum til usannsynlige diagnoser. Selv med ekkokardiografi uten sikre tegn til perikarditt, ble fremmedlyden som tydelig kunne høres over hele prekordiet utslagsgivende for diagnosen perikarditt.

Kort tid etter utskrivning gjennomførte pasienten en lengre flyreise. Ikke lenge etter ankomst fikk pasienten brystsmerter på nytt, og ble innlagt i sykehus. Der ble det påvist pneumothorax.

Opplysninger om dette førte til ny gjennomgang av innleggelsen i vårt sykehus. Ved nøye inspeksjon av røntgenbildene av lungene kunne vi se en liten, apikal luftkappe på venstre side som målte ca. 12 mm i ekspirasjon (fig 1).

Et søk i PubMed med stikkordene perikarditt og pneumothorax identifiserte artikler som beskrev tilstanden «noisy» eller «click-

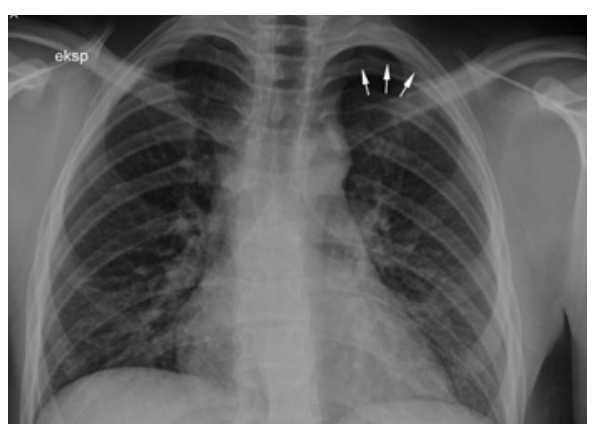

Figur 1 Røntgen thorax tatt under ekspirasjon viser en $12 \mathrm{~mm}$ apikal luftkappe på venstre side 
ing» pneumothorax («støyende» pneumothorax), en tilstand hvor pasientene har pneumothorax med tillegg av pulssynkron fremmedlyd fra brystkassen (4-8).

Symptomene til vår pasient samsvarer med symptomene beskrevet i litteraturen: brystsmerter, forverring ved innpust, «surklelyd» fra apexområdet og spredning av denne lyden over prekordiet. Vi antar derfor at pasienten hadde en slik støyende pneumothorax og ikke perikarditt, som først antatt.

\section{Diskusjon}

I litteraturen beskrives flere liknende tilfeller hvor pasienten først har fått diagnosen perikarditt, for senere å få diagnosen pneumothorax ved ny gjennomgang av røntgenbildene (4-8). Pneumothorax er ansamling av luft i rommet mellom viscerale og parietale pleura. En pnemothorax kalles spontan dersom det ikke kan påvises noen utløsende hendelse. Studier både fra Norge og USA har vist at tilstanden er tre ganger hyppigere hos menn enn hos kvinner $(9,10)$. En spontan pneumothorax oppstår vanligvis ved at en apikal, subpleural emfysemblære sprekker. Røykere har økt risiko og personer med spontan pneumothorax har en tendens til å være høyere enn kontrollpasienter $(11,12)$.

Støyende pneumothorax er beskrevet flere ganger i litteraturen i form av pasientkasuistikker (4-8). Et materiale angir at under $1 \%$ av de spontane pneumothoraxtilfellene er støyende pneumothorax, et annet opptil ett av seks tilfeller $(5,6)$.

Lyden som høres ved en støyende pneumothorax, beskrives i litteraturen som skrapende, boblende, klikkende eller knasende. Denne lyden kalles også Hammans tegn og ble i utgangspunktet beskrevet av Louis Hamman i 1937, i forbindelse med pneumomediastinum (13). Pneumomediastinum er luft i mediastinum og kan oppstå spontant, etter skader eller i forbindelse med endring $\mathrm{i}$ intratorakalt trykk som ved astmaanfall, oppkast eller tannlegebesøk hvor trykkluft brukes (14). Det er i tilfeller med fremmedlyd over prekordiet ekstra viktig å vurdere muligheten for luft i mediastinum. I noen tilfeller med pneumomediastinum finner man også subkutant emfysem.

Gnidningslyden ved støyende pneumothorax oppstår når hjertets mekaniske arbeid skaper bevegelse av små luftmengder intrapleuralt (7). Lyden oppstår hyppigst ved venstresidige, små, apikale luftkapper og høres ofte sterkest i venstre sideleie. Det er kun beskrevet ett tilfelle av høyresidig pneumothorax sammen med slik fremmedlyd (6). Fonografiske studier har vist at det ofte er flere fremmedlyder, både $\mathrm{i}$ systole og diastole, og at de kan variere med respirasjonssyklus og kroppsposisjon (15).

Vanlig stående røntgen thorax med posterioanterior strålegang er vanligvis nok for å stille diagnosen pneumothorax. Bilder tatt i ekspirasjon anbefales ikke som del av vanlig rutineutredning (12). Små luftkapper kan være vanskelige å oppdage, og det er fort gjort å overse en liten pneumothorax, spesielt dersom man ikke aktivt leter etter en. På stående bilder ses vanligvis en apikal hyperklar sone med synlig kontur av viscerale pleura og manglende kartegninger perifert. På liggende bilder kan det være vanskeligere å diagnostisere en pneumothorax siden luften stiger opp mot det høyeste punktet og dermed legger seg anteriomedialt mot basis av lungen (16).

En pneumothorax kan behandles på ulike måter, avhengig av årsak, symptomer, luftkappens størrelse og om det er en tilbakevendende tilstand. Det finnes ikke egne retningslinjer for behandling av støyende pneumothorax. British Thoracic Society har utarbeidet generelle retningslinjer for behandling av spontan pneumothorax (12). Små luftkapper kan, ifølge disse retningslinjene, følges poliklinisk, mens større eller residiverende luftkapper bør behandles med aspirasjon, surstoff, dren eller pleurodese, avhengig av størrelse, antall residiver og symptomer.

Gjennomgått spontan pneumothorax kan få konsekvenser for valg av yrke og fritidsaktiviteter. Slike pasienter bør skjermes for barotraumer (hurtige endringer i lufttrykk). Tidligere spontan pneumothorax er en kontraindikasjon mot dykking med trykkflasker dersom den ikke er behandlet med bilateral pleurektomi (17). Faren ligger i at luft utvider seg når trykket reduseres under oppstigning fra et dykk. Pasienter som har hatt pneumothorax bør også være forsiktig med tanke på flyreiser (18). Lufttrykket i flykabinen er lavere enn trykket på bakken og dette kan føre til at en pneumothorax utvider seg. Utvidelsen av luft ved lavere trykk vil også kunne disponere for utviklingen av en tensjonpneumothorax, som er et medisinsk nødtilfelle. En tensjonspneumothorax utvikler seg ved at det danner seg en enveisventil som slipper luft inn i pleurahulen men ikke ut igjen. I britiske retningslinjer blir det anbefalt røntgen thorax for å bekrefte full tilbakegang av pneumothorax før flyreiser, samt å vente ca. sju dager ekstra etter normalisering (18).

Hos vår pasient kan selve flyreisen ha vært en medvirkende årsak både til residivet av smertene og til diagnostiseringen. Det lave barometertrykket i kabinen kan ha ført til at luftkappen utvidet seg i løpet av flyturen.

Det er lett å være etterpåklok. Observasjon av om gnidningslyden var synkron med respirasjon eller puls, kunne til en viss grad ha vært til hjelp i diagnostikken. Mens en gnidningslyd forårsaket av perikarditt eller støyende pneumothorax vil være synkron med hjerterytmen, vil fremmedlyden ved for eksempel pleuritt opphøre hvis man holder pusten. Det er selvfølgelig også beklagelig at luftkappen apikalt på røntgen thorax i ekspirasjon ikke ble oppdaget ved første gjennomgang av bildene. På den annen side har vi med dette fått en påminnelse om hvor viktig det er å holde seg oppdatert også når det gjelder mer sjeldne diagnoser. I vårt tilfelle kunne pasientens tilstand utviklet seg i alvorlig retning i forbin- delse med den mange timers lange flyreisen han tok etter utskrivning fra vår avdeling. En korrekt diagnose i utgangspunktet ville ha forhindret dette.

Pasienten har gitt samtykke til at artikkelen blir publisert.

\section{Marit Høysæter Hedger (f. 1983)}

er lege i spesialisering i radiologi ved Ålesund sjukehus.

Forfatter har fylt ut ICMJE-skjemaet og oppgir ingen interessekonflikter.

\section{Sahrai Saeed (f. 1975)}

er lege i spesialisering i hjertesykdommer ved Haukeland universitetssykehus.

Forfatter har fylt ut ICMJE-skjemaet og oppgir ingen interessekonflikter.

\section{Litteratur}

1. Horne NW. Spontaneous pneumothorax: diagnosis and management. BMJ 1966; 1: 281-4.

2. Le Gall F, Herne N, Marion J et al. «Pericardial» friction rubs in pulmonary embolism lauthor's transll. Sem Hop 1982: 58: 1480-4.

3. Greenberg DI, Davia JE, Fenoglio J et al. Dissecting aortic aneurysm manifesting as acute pericarditis. Arch Intern Med 1979; 139: 108-9.

4. Andersen K, Hammerstrøm J. Støyende pneumothorax. Tidsskr Nor Lægeforen 1978: 98: 946-8.

5. Baumann MH, Sahn SA. Hamman's sign revisited. Pneumothorax or pneumomediastinum? Chest 1992; 102: $1281-2$

6. Semple T, Lancaster WM. Noisy pneumothorax BMJ 1961: 1: 1342-6.

7. Drury NE, Gnanapragasam JP. Recurrent noisy pneumothorax mimicking pericarditis. Int J Cardiol 2006; 113: 104-5

8. Midttun M, Videbaek J. Noisy pneumothorax. Kappepneumothorax forkledt som pericarditis. Ugeskr Læger 1993; 155: 1878-80.

9. Eggen T, Sørlie D. Spontan pneumothorax - et tiårsmateriale fra Regionsykehuset i Troms $\varnothing$. Tidsskr Nor Lægeforen 2000: 120: 3513-5.

10. Noppen M, De Keukeleire T. Pneumothorax. Respiration 2008; 76: $121-7$

11. Jørstad $S \varnothing$, Nygaard IH. Spontan pneumothorax. Analyse av et 17 års materiale. Tidsskr Nor Lægeforen 1982: 102: 1497-500.

12. Macduff A, Arnold A, Harvey J. Management of spontaneous pneumothorax: British Thoracic Society Pleural Disease Guideline 2010. Thorax 2010; 65 (suppl 2): ii18-31.

13. Hamman L. Spontaneous interstitial emphysema of the lungs. Trans Assoc Am Physicians 1937; 52 $311-9$.

14. Caceres M, Ali SZ, Braud R et al. Spontaneous pneumomediastinum: a comparative study and review of the literature. Ann Thorac Surg 2008; 86: $962-6$.

15. Roelandt J, Willems J, van der Hauwaert LG et al. Clicks and sounds (whoops) in left-sided pneumothorax. Clinical and phonocardiographic study. Dis Chest 1969; 56: 31-6

16. Cummin AR, Smith MJ, Wilson AG. Pneumothorax in the supine patient. Br Med J (Clin Res Ed) 1987; 295. 591-2. (Clin Res Ed).

17. British Thoracic Society guidelines on respiratory aspects of fitness for diving. Thorax 2003; 58 $3-13$

18. Ahmedzai S, Balfour-Lynn IM, Bewick T et al. Managing passengers with stable respiratory disease planning air travel: British Thoracic Society recommendations. Thorax 2011; 66 (suppl 1): i1-30.

Mottatt 4.5. 2011, første revisjon innsendt 16.11 2011, godkjent 12.4.2012. Medisinsk redaktør Kristin Viste. 